\title{
K najnovšej libertariánskej polemike o evikcionizme
}

\author{
Turčan, M.*
}

TURČAN, M.: K najnovšej libertariánskej polemike o evikcionizme. Právny obzor, 104, 2021 , č. 1 , s. $54-65$.

On the Latest Libertarian Controversy about Evictionism. The paper deals with the libertarian conception of evictionism, as formulated by Walter Block, and its latest critique by Kerry Baldwin. Both base their views on the value of private property, which includes body ownership, and both are opposed to current abortion practices. However, they differ in the question of the admissibility of the fatal ,eviction“ of the fetus from the mother's body. In the paper the author critically analyzes their arguments and concludes that, from the perspective of Rothbardian libertarianism, Block's conception is basically more persuasive, but only if it is slightly modified.

Key words: abortion, right to life, ownership, negative rights, liberty

\section{Úvod}

Evikcionizmus je jednou z teórií, ktoré sa dnes pokúšajú o spoločensky spravodlivé riešenie otázky umelého prerušenia tehotenstva. ${ }^{1}$ Oproti tradičným pozíciám pro-life a pro-choice striktne nefavorizuje ani právo plodu ${ }^{2}$ na život, ani právo ženy na súkromie, ale snaží sa obe istým spôsobom vybalansovat'. Vd’aka tomu ho možno označit' za akúsi „stredovú pozíciu“.

Ide o libertariánsku koncepciu, ktorú, vychádzajúc z myšlienok Johna Locka a Murraya Rothbarda, sformuloval Walter Block, profesor ekonómie na Loyola University v New Orleans. ${ }^{3}$ Pred niekol'kými rokmi prebehala medzi Blockom a niektorými d’alšími liberatariánmi, pomerne vitálna diskusia o (ne)presvedčivosti tejto teórie z hl'adiska libertarianizmu. ${ }^{4}$ Následne táto diskusia na čas utíchla, no minulý rok ju novým spôsobom oživila libertariánska filozofka Kerry Baldwinová. ${ }^{5}$

* Doc. JUDr. Mgr. Martin T u r č a n, PhD., Katedra teórie práva a sociálnych vied, Právnická fakulta, Univerzita Komenského v Bratislave.

${ }^{1}$ Otázka umelého prerušenia tehotenstva patrí, samozrejme, medzi „večné témy“. V kontexte hodnotenia právnoaplikačnej praxe v ČR pozri k tejto problematike z relatívne novších prác napríklad príspevok Jakuba Valca z r. 2016 (VALC, J. Má opravdu „každý“ " právo na život? In Časopis pro právní vědu a praxi. 2016 (roč. 24), č. 4, s. 597 - 605), i jeho celkom novú dizertáciu, v ktorej sa danou problematikou zaoberá komplexnejšie (VALC, J. Rekonstrukce práva na život v kontextu vývoje genetických technologií (filozoficko-právní analýza problému). Brno : Právnická fakulta Masarykovy univerzity, 2020, 237 s.).

${ }^{2} \mathrm{~V}$ tomto príspevku nebudem rozlišovat' medzi pojmami zygóta, embryo a plod. Budem zjednodušujúco používat' len pojem plod, ktorý z praktických dôvodov vztiahnem na všetky tieto významy.

${ }^{3}$ Prvý raz danú koncepciu Block načrtol už v r. 1977 (BLOCK, W, E. Toward a Libertarian Theory of Abortion. In The Libertarian Forum, 1977 (roč. 10), č. 9, s. 6 - 8). Pozornost’ jej však bola venovaná v zásade až $\mathrm{v}$ tomto tisícročí. Block k téme evikcionizmu publikoval viacero článkov [pozri napríklad: BLOCK, W. E. Toward a Libertarian Theory of Evictionism. In Journal of Family and Economic Issues, 2014 ([roč. 35), s. 290 - 294].

${ }^{4}$ Šlo najmä o námietky Jakuba Wiśniewskeho (pozri napríklad: WIŚNIEWSKI, J. B. Abortion, Libertarianism, and Evictionism: A Last Word. In Libertarian Papers, 2013 (roč. 5), č. 1, s. 153 - 162). K polemike sa neskôr pridal Timothy Grisillo [pozri: GRISILLO, T. Block versus Wiśniewski: Not Over Yet, In Reason Papers, 2015 (roč. 37), č. 2, s. $76-78]$.

${ }^{5}$ Reason TV: „What's The Correct Libertarian Position on Abortion? A Soho Forum Debate,“ online: https://www.youtube.com/watch?v=OKU_xutF-eQ [07-09-2020]. Block skonštatoval, že jej námietky sú rozhodne hodné pozornosti. 
V tomto príspevku sa zameriam na analýzu polemiky medzi Blockom a Baldwinovou. Najskôr stručne popíšem Blockovu koncepciu evikcionizmu (ktorá je zrejme nejednému čitatel'ovi úplne neznáma) a následne si všimnem Baldwinovej námietky. Argumenty oboch kriticky preskúmam, pričom metóda môjho skúmania bude spočívat' v posudzovaní logickej konzistentnosti jednotlivých tvrdení, ako aj v posudzovaní ich súladu so základnými ideovými východiskami rothbardovského libertarianizmu (pôjde teda v podstate o kritiku ,zvnútra“). ${ }^{6}$ Svoje zistenia zhrniem v závere.

\section{Blockova koncepcia evikcionizmu}

Evikcionistická teória Waltera Blocka je relatívne jednoduchá. Block vychádza z lockovskej myšlienky seba-vlastnenia, teda $\mathrm{z}$ tézy, že každý človek je majitel’om samého seba. Túto predstavu v 20. storočí hlbšie rozvinul Blockov vel'ký vzor, M. N. Rothbard, ktorý sformuloval teóriu anarcho-kapitalizmu (ktorú predstavil najmä v diele Etika slobody). ${ }^{7}$ Anarcho-kapitalisti tvoria krajné krídlo pravicového libertarianizmu. Volajú po úplnom zrušení štátu a veria $\mathrm{v}$ principiálnu správnost' a reálnu dosiahnutel'nost' idey slobodného života bezštátnej spoločnosti, ktorá sa bude spravovat' výlučne normami prirodzeného práva (pričom v situácii existencie štátu volajú po jeho postupnom zoštíhl'ovaní). Základom prirodzeno-právnych noriem je tu už spomínaný pojem súkromného vlastníctva, ktoré anarcho-kapitalisti chápu ako zmiešanie vlastnej práce s vecou nikoho (čo je, samozrejme, koncept rovnako prevzatý od Locka). ${ }^{8}$ Okrem prvotného nadobudnutia možno podl'a nich vlastníctvo nadobúdat', pochopitel'ne, i na základe zmluvného prevodu. ${ }^{9}$

Ako už som uviedol, anarcho-kapitalisti predpokladajú, že človek je vlastníkom svojho tela. Znamená to, že so svojím telom smie nakladat' akýmkol'vek spôsobom, pokým nezasahuje do súkromného vlastníctva druhých. Dôraz je kladený na negatívne práva ${ }^{10}$ a na tzv. principe neagresie, čo znamená, že každý smie konat’ to, čo nenarúša nárokovatel'né majetkové práva iných.

Na základe týchto predpokladov bol Rothbard v otázke umelého prerušenia tehotenstva zástancom pozície pro-choice. Jeho nasledovník Walter Block však dospel k záveru, že Rothbardov názor je $\mathrm{v}$ tomto ohl'ade mylný a treba ho korigovat'. Vytvoril teda koncepciu, ktorej podstatou je myšlienka, že žena ako vlastníčka svojho tela smie plod „,vyhostit"“ (odtial' názov evikcionizmus; z anglického to evict = vyhostit'), avšak nesmie ho pritom priamo usmrtit'. Dôvodom tohto limitu je práve princíp neagresie. Block totiž predpokladá, že plod je l'udská bytost' ( $\mathrm{z}$ tohto hl'adiska vlastne súhlasí s proponentmi

\footnotetext{
${ }^{6}$ Hoci osobne sa za rothbardiána nepovažujem.

${ }^{7}$ V našom, resp. nám blízkom, jazykovom prostredí pozri preklad daného diela do češtiny: ROTHBARD, M. N. Etika Svobody. Praha : Liberální institut, 2009, 336 s.

${ }^{8}$ LOCKE, J. Two Treatises of Government. Londýn : Thomas Tegg and Co., 1823, s. 116.

${ }^{9}$ Pričom pod vlastníctvom rozumejú nielen práva k veciam, ktoré človek drží, užíva a ktorými disponuje, ale aj k tomu, na čo má človek právo z nájomnej zmluvy, pracovnej zmluvy či akejkol'vek inej zmluvy.

${ }^{10} \mathrm{~K}$ pojmu negatívnych práv pozri napríklad: BERLIN, I. Čtyři eseje o svobodě. Praha : Prostor, 1999, s. 213 a n.
} 
pozície pro-life), bytost', ktorá tiež disponuje negatívnym právom nebyt' usmrtený. Ked'že však plod „nevlastní“ matkino telo, ale je v ňom len „,na návšteve,“ vlastníčka má právo kedykol'vek ho zo svojho tela „vyhostit"“ ako nežiaducu osobu (ako „votrelca“, ktorý viac „nie je vítaný").

Ak to žena spraví v prvom trimestri, plod po akokol'vek šetrnom medicínskom vyňatí z jej tela, samozrejme, zomrie. Zatial' neexistuje inkubátor, ktorý by takýto organizmus udržal pri živote (z tohto hl'adiska sa teda Block ponáša na pro-choicera). Plod však $\mathrm{v}$ tomto prípade nebude zabitý, iba ho nechajú umriet' (zaživa ho vyberú z tela matky a on až následne zomrie).

Táto skutočnost' je podl'a Blocka zásadne dôležitá. Evikcionizmus vd’aka nej nepripúšt’a metódy, ktoré sa dnes bežne používajú pri umelom prerušení tehotenstva (ako je napr. kyretáž), pretože pri nich dochádza k priamemu spôsobeniu smrti plodu (smrt' plodu je tu dokonca výslovne želaná). Z hl'adiska evikcionizmu je akceptovatel'ná len predvídaná, no nechcená smrt' plodu, ktorý sa ocitne v prostredí, na ktoré zatial', žial', nie je uspôsobený.

Block je teda vlastne v jadre pro-liferom, akurát vzhl'adom na radikálny libertariánsky dôraz na zvrchovanost' idey súkromného vlastníctva a koncept negatívnych práv, je v praktických dôsledkoch akoby pro-choicerom (i ked' výrazne reštriktívnym, ked’že odmieta bežné interrupčné techniky). V rámci svojich libertariánskych východísk striktne rozlišuje medzi zabitím a nechaním zomriet', pričom zabitie chápe ako aktívne spôsobenie smrti, nechanie zomriet' ako pasívne (ide „len“ o nezachránenie). Podl’a Blocka totiž neexistuje žiadne právo na aktívnu pomoc (záchranu), pretože by šlo o pozitívne oprávnenie, a libertariáni v legitimitu pozitívnych práv neveria. Uznávajú len negatívne práva - právo na neubližovanie, resp. na nenarúšanie súkromného vlastníctva. Nikto teda nemôže byt' spoločnost'ou nútený pomôct' blížnemu. Každý môže byt' len nútený, aby nikomu aktívne neubližoval zásahom do jeho súkromnej sféry. ${ }^{11}$

\footnotetext{
${ }^{11}$ Block v daných súvislostiach uvádza príklad stroskotanca na mori, ktorý podl’a neho nemá právo (nárok) žiadat', aby bol vzatý do lode, ktorá sa pri ňom objaví. Môže len prosit', aby ho na lod' vzali, pričom rozhodnutie, či mu bude alebo nebude umožnené do lode nastúpit', je na jej majitel'ovi, resp. na tom, kto má k nej aktuálne majetkové právo. Ak by stroskotanec do lode vliezol bez povolenia, smie byt' po neuposlúchnutí výzvy na jej opustenie vyhodený do mora. Ak sa po čase v mori utopí (pretože už nebude viac vládat' plávat'), nebol zabitý, len ho nechali zomriet' (čo znamená, že princíp neagresie ostal dodržaný, pretože obrana proti agresorovi nie je agresiou). Ak by ho však priamo na lodi zabili a jeho mítve telo hodili do mora, došlo by k porušeniu pricípu neagresie, hoci konečný výsledok by bol v oboch prípadoch rovnaký. (Patterson in Pursuit: „Ep. 93 Abortion, Natural Rights, and Evictionism | Dr. Walter Block“, online: https://www.youtube.com/watch?$\mathrm{v}=$ W5ECeLv8BBU [07-09-2020]. Tento príklad Block v podstate preberá od Rothbarda; pozri: ROTHBARD, M. N. Etika Svobody. Praha : Liberální institut, 2009, s. 198 - 200). Konzekvencialisti by v týchto dvoch situáciách, samozrejme, morálne relevantný rozdiel nevideli. (K tejto problematike pozri napríklad: ČERNÝ, D. Princip dvojího účinku: zabijení v mezích morálky. Praha : Academia, 2016). Blockova koncepcia však nie je konzekvencialistická, ale deontologická. Vychádza z idey prirodzeného zákona a nárokovatel’ných negatívnych majetkových práv, nie z kalkulu spoločenského úžitku či iného „dôsledkového“ kritéria. Podotýkam pritom, že nejde o individuálno-etickú teóriu. Block žiadnemu majitel’ovi lode neradí, aby stroskotanca vyhodil z člna, ani tehotnú ženu nenabáda, aby plod ,vyhostila“ zo svojho tela. Netvrdí, že takéto konanie je morálne správne či akceptovatel'né. Ide o sociálno-etickú teóriu (resp. o súčast' určitej sociálnoetickej teórie), čiže o koncepciu, ktorá sa venuje len otázke spravodlivosti v spoločnosti, nie v osobnom živote jednotlivcov. Block teda tvrdí iba tol'ko, že by bolo nespravodlivé nútit' majitel'a lode, aby do nej stroskotanca vzal, rovnako ako
} 
„Vyhostenie“ plodu v prvom trimestri dnes, pochopitel'ne, znamená pre plod istú smrt' (hoci nezamýšl'anú, iba predvídanú smrt'). Block však tvrdí, že vzhl'adom na vedecko-technický pokrok možno predpokladat', že v budúcnosti budú vyvinuté inkubátory, v ktorých bude možné zaistit’ prežitie i takýchto „prvotrimestrálnych“ detí. Počíta dokonca s tým, že budú vyvinuté umelé maternice, v ktorých bude možné zabezpečit' úplný vývin človeka od momentu počatia. Evikcionizmus teda podla Blocka v budúcnosti povedie $\mathrm{k}$ záchrane vel'kého množstva detí, ktoré sú dnes umelo potrácané. ${ }^{12}$

Tieto pomyselné (kladné) dôsledky evikcionizmu pro futuro sú však len Blockovým podporným argumentom, nie sú t’ažiskovým ospravedlnením jeho teórie. Striktne vzaté, podl'a Blocka nezáleží na tom, aké praktické dôsledky má evikcionizmus dnes, a aké bude mat' v budúcnosti. Ako som totiž uviedol, evickionizmus nie je koncekvencialistickou, ale deontologickou teóriou. Ide o otázku princípov. Block nazýva evickionizmus aj zásadovým kompromisom (principled compromise), ktorý z oboch krajných pozícií (pro-life a pro-choice) vyberá t’ažiskové princípy (ktorými sú právo na život a právo na súkromie) a tieto vyvažuje vo svetle rothbardovského chápania pojmu súkromného vlastníctva a konceptu negatívnych individuálnych prirodzených práv.

\section{Baldwinovej kritika}

Evikcionizmus je kritizovaný zo strany pro-liferov i pro-choicerov, a to, samozrejme, aj „z vlastných“, libertariánskych radov. Libertariánsky autor Jakub Wiśniewski napríklad voči evikcionizmu prednedávnom argumentoval, že žiadny vlastník nemôže vyhostit' iného do potenciálne smrtel'ných podmienok, pretože by šlo o porušenie princípu neagresie. ${ }^{13}$ Block na Wiśniewskeho námietky reagoval niekol'kými článkami v časopise Libertarian Papers. ${ }^{14}$

Najnovšie prišla s kritikou evikcionizmu Kerry Baldwinová, ktorá argumentuje na základe pojmu narušitel'a či votrelca (angl. trespasser). Tento pojem je podl'a nej v hodnotení evikcionizmu kl’účový. Sám Block ním označuje nežiaduci plod. Baldwinová tvrdí, že plod nemôže byt' ,votrelcom“, pretože neprekročil žiadnu priestorovú hranicu, cez ktorú by vnikol na ženin majetok, teda do jej tela. Plod predsa neprichádza do matkinho

by bolo nespravodlivé nútit' tehotnú ženu, aby svoj plod donosila, pretože by tým došlo k násiliu voči ich slobode vol'ne nakladat' so svojím vlastníctvom (a to bez ohl'adu na to, ako vel'mi nemorálne, a to objektívne nemorálne, by ich konanie bolo na individuálnoetickej úrovni, kde ich musí súdit’ vlastné svedomie, Boh alebo nejaká iná inštancia, nie spoločnost' svojimi donucovacími opatreniami).

${ }^{12}$ Patterson in Pursuit: „Ep. 93 - Abortion, Natural Rights, and Evictionism | Dr. Walter Block“, online: https://www.youtube.com/watch?v=W5ECeLv8BBU [07-09-2020]. Malo by však podl'a neho íst' o súkromné dobrovol'né aktivity tých, čo budú chciet' takúto starostlivost' zabezpečit'. Block v ideálnom prípade nepočíta so štátom, v neideálnom prípade počíta s čo najmenším štátom. Ideu evikcionizmu každopádne navrhuje implementovat' už do súčasnej legislatívy.

${ }^{13}$ WIŚNIEWSKI, J. B. A Critique of Block on Abortion and Child Abandonment. In Libertarian Papers, 2010 (roč. 2), čl. č. 16, s. 1 - 4; WIŚNIEWSKI, J. B. Rejoinder to Block's Defense of Evictionism. In Libertarian Papers, 2010 (roč. 2), čl. č. 37, s. $1-7$.

${ }^{14} \mathrm{~K}$ Blockovej reakcii pozri napríklad: BLOCK, W. E. Response to Wisniewski on Abortion, Round Two. In Libertarian Papers, 2011 (roč. 3), čl. č. 4, s. 1 - 10; BLOCK, W. E. Response to Wisniewski on Abortion, Round Three. In Libertarian Papers, 2011 (roč. 3), čl. č. 37, s. 1 - 6. 
organizmu zvonku, on v ňom priamo vzniká. Bud' teda vznikne vnútri matky, alebo nevznikne vôbec.

Ak však plod nie je ,votrelcom“, nemožno s ním ako s „votrelcom“ zaobchádzat'. Nemožno ho teda z tela svojvol'ne, ,vyhostit"“.

Žiada sa dodat', že ani podl'a Baldwinovej nie je matka povinná nosit' plod vo svojom vnútri až do dňa pôrodu. Tvrdí, že matkina povinnost' je obmedzená na čas, kým plod nie je schopný prežit' mimo jej tela, a to aspoň s umelou pomocou. Po tomto čase má podl'a Baldwinovej matka právo plod „vyhostit“", ${ }^{15}$ musí však zabezpečit' jeho prežitie (v inkubátore). ${ }^{16}$ Baldwinová argumentuje, že tehotenstvo predstavuje unikátny vzt'ah medzi matkou a jej plodom, ktorého súčast'ou je aj prirodzený záväzok matky postarat' sa o svoje diet’a. Tento záväzok je daný prirodzenými biologickými procesmi oboch organizmov. ${ }^{17}$ Baldwinová odmieta, že by šlo o také právo plodu na zaopatrenie, ktoré by bolo $\mathrm{v}$ rozpore $\mathrm{s}$ libertariánskymi hodnotami a princípmi. Záväzok matky postarat' sa o nového „majitel’a samého seba“ (self-owner), ktorý v nej vznikol, je podl’a Baldwinovej prirodzenoprávnym záväzkom, a to vzhl'adom na skutočnost', že je plne v súlade s prirodzenými (biologickými) procesmi jej tela i tela plodu. Musí byt’ teda uznaný ako legitímny.

Svoju argumentáciu Baldwinová podopiera aj tvrdením, že ak by mala žena prirodzené právo „vyhostit“" plod kedykol’vek zo svojho tela, ako tvrdí Block, potom by každý z nás existoval len vd’aka altruizmu svojej matky a naše práva by boli kontingentné, nie absolútne (záviseli by od rozhodnutia inej osoby, nie výlučne od našej prirodzenosti ako l’udských bytostí). Podl'a Baldwinovej by šlo o matriarchát, nie o libertarianizmus. Zdôrazňuje, že v blockovskej logike platí, že každý z nás je principiálne počatý ako „votrelec a kriminálnik“ (trespasser and criminal), ${ }^{18}$ ktorý je napokon donosený len vd’aka matkinmu dobrovol'nému postoju. Ak nám však naše práva patria nie preto, že sa tak rozhodla naša matka, ale výlučne preto, že sme l’udskými bytost’ami, „vlastníkmi samých seba“, a ak existujeme ako l'udské bytosti, „vlastníci samých seba“, od momentu počatia, potom v tomto prvom momente našej existencie nemôžeme byt’ v žiadnom prípade označení za „,votrelcov“ či „,kriminálnikov“, pretože inak by naša existencia bola už vo svojom najranejšom štádiu nelegitímna (ked’že prirodzeným spôsobom nemôžeme vzniknút' inak ako v tele matky, a to bez jej vedomia; samotné počatie je totiž mimovolný biologický proces, hoci je pôvodne iniciovaný vôl'ovým aktom pohlavného styku).

\footnotetext{
${ }^{15}$ Pričom na označenie vyhostenia nepouživa termín eviction, ale emancipation. Svoju teóriu na základe toho nazýva teóriou emancipácie.

${ }^{16}$ Baldwinová teda vlastne nekritizuje evikcionizmus en bloc, ale len určitý jeho aspekt. Tým však prakticky z evikcionizmu robí čistú pro-life teóriu (jednu z libertariánskych verzí pro-life).

${ }^{17}$ Podotýka, že matkino telo sa prirodzene správa tak, aby plodu umožnilo vzniknút' a rozvinút' sa, pričom čiastočné pnutie medzi oboma organizmami (ako napríklad zabezpečenie sa zo strany zygóty voči matkinej imunite) chápe ako biologický doklad kontroly plodu nad vlastným telom, ktorá je relatívne nezávislá od tela matky, teda ako doklad skutočnosti, že plod (resp. už zygóta) je „vlastníkom samého seba“ (k tomu pozri napríklad: Libertarian Christian Institute: „Ep 64: The Abortion Debate with Kerry Baldwin“, online: https:// www.youtube.com/watch?v=ASvZ21YQ8H4 [11-09-2020].

${ }^{18}$ Sú to termíny, ktoré sám Block používa na označenie nežiaduceho plodu.
} 
Ani znásilnenie podl'a Baldwinovej nie je skutočnost’ou, ktorá by legitimizovala fatálne „vyhostenie“ plodu z tela ženy. Je len dôvodom na uloženie povinnosti násilníkovi kompenzovat’ žene spôsobenú ujmu a v prípade „vyhostenia“ životaschopného plodu uhradit' náklady na zabezpečenie jeho prežitia. ${ }^{19}$

\section{Diskusia}

Je zrejmé, že Baldwinovej argumentácia sa zakladá na odlišnom chápaní pojmu votrelca, než s akým pracuje Block. Podla Blocka na označenie niekoho za votrelca postačuje skutočnost', že dotyčný sa nachádza na cudzom majetku bez súhlasu vlastníka. Nie je dôležité, ako sa tam ocitol. Pokojne môže íst’ o „nevinného votrelca“ (Block explicitne používa pojmy ako ,inncent trespasser“, „innocent criminal“). Z neviny votrelca však nevyplýva majitel'ova povinnost' tolerovat' ho na svojom území. Nie je dôležité, či niekoho omámia a prenesú na susedov pozemok, alebo tam príde dobrovol'ne. Nie je dôležité ani to, či tam iba vznikne (začne existovat'), ako je to v prípade počatia. Dôležité je, že sa nachádza v priestore, na ktorý nemá majetkové právo. To postačuje, aby sme ho označili za votrelca, narušitel'a (trespasser). ${ }^{20} \mathrm{Ak}$ si teda žena neželá, aby sa plod nachádzal v jej vnútri, ide v každom prípade o „votrelca“, „,narušitel'a“.

Na základe uvedených námietok Kerry Baldwinovej možno povedat', že ona s takýmto chápaním nesúhlasí z troch dôvodoch:

(1) Prvý dôvod je jazykovoanalytický: Ak je niekto votrelec, narušitel', musel prekročit' (priestorovú) hranicu majetku druhého. To zároveň znamená, že musel existovat' skôr, než došlo k prekročeniu danej hranice, inak by v pravom zmysle slova nemohol nič „,narušit “", nikam by sa nedokázal „,votriet'““ (pretože ešte neexistuje); teda nemohol by byt' „narušitel'om“, ,votrelcom“.

Tento dôvod znie síce na prvý pohl'ad relevantne, má však jeden nedostatok: nie je rozhodujúce, aké pojmy budeme pri koncipovaní určitej teórie alebo pri jej obhajobe používat'. Rozhodujúce je, aký je celkový zmysel nami komunikovanej myšlienky. Block, ktorý na svojom chápaní pojmu votrelca (trespasser) trvá, sa tohto chápania môže pokojne vzdat' a namiesto neho použit' nejaký iný pojem, ktorý lepšie vystihne jeho definíciu (a to tak, aby nenarážala na Baldwinovej jazykovoanalytickú výhradu).

(2) Baldwinovej druhý dôvod je prirodzenoprávny: Baldwinová argumentuje, že matka má prirodzený záväzok postarat' sa o svoj plod a že tento záväzok vyplýva z biologických zákonitostí oboch organizmov. Vzt'ah medzi matkou a plodom je podl'a nej

${ }^{19}$ Baldwinová zatial' svoje názory neprezentovala písomne. Urobila tak len v živej polemike s Blockom a v poskytnutých rozhovoroch (Reason TV: „What's The Correct Libertarian Position on Abortion? A Soho Forum Debate,“ online: https://www.youtube.com/watch?v=OKU_xutF-eQ [07-09-2020]; CLAIR, M. A Paradigm Shift on Abortion? Kerry Baldwin Makes a Libertarian Case for a New Perspective. In Lions of Liberty, online: https://lionsofliberty.com/2020/02/03/26228/?utm_source=rss\&utm_medium=rss\&utm_campaign=26228 [0909-2020]; Free Man Beyond the Wall Peter R Quinones: „Episode 357: Kerry Baldwin On Her Abortion Debate With Walter Block“, online: https://www.youtube.com/watch?v=NhJ5oDekKsI [09-09-2020]).

${ }^{20} \mathrm{~V}$ prípade počatia nie je podla Blocka dôležité ani to, či šlo o dobrovol'ný styk alebo o znásilnenie (s čím Baldwinová, ako sme videli, súhlasí, no dospieva k odlišným záverom). 
unikátny a nemožno ho prirovnávat' $\mathrm{k}$ prítomnosti nežiaduceho host'a $\mathrm{v}$ dome ani $\mathrm{k}$ inej podobnej situácii, pretože pri ňom ide o otázku prirodzených biologických procesov (aj preto teda plod nemôže byt' ,votrelcom“).

Tvrdenie, že záväzok matky postarat' sa o svoje diet’a vyplýva z prirodzeného práva, pretože vznik nového človeka (zygóty) je mimovol'nou biologickou skutočnost'ou, ${ }^{21}$ azda trochu pripomína tomistický argument zo zneužitia schopnosti, ktorý je dnes mnohými

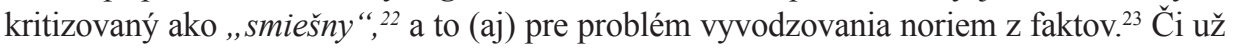
tu však určité paralely existujú alebo nie, Baldwinovej druhý dôvod je v každom prípade náchylný na kritiku za naturalistický omyl (is - ought fallacy). Tento problém síce sám Rothbard odmieta brat' príliš vážne ${ }^{24}$ (a celá jeho koncepcia ním v zásade trpí), takže by sme mohli uvažovat', že z hl'adiska rothbardovského libertarianizmu nie je táto výhrada podstatná, avšak otázkou je, či Baldwinová v poukaze na prirodzené (biologické) procesy vo svojej koncepcii tento problém ešte viac neprehlbuje. Predsa len sa javí trochu iné kritizovat' prizmou naturalistického omylu premyslené teórie prirodzeného zákona vychádzajúce z nejakej prepracovanej koncepcie praktického rozumu a kritizovat' ňou holé vyvodzovanie morálneho záväzku z biologických zákonitostí l'udského tela.

(3) Baldwinová pridáva tretí dôvod, ktorý má oba predchádzajúce dôvody doplnit' a podporit'. Je ním argument $\mathrm{z}$ absolútnej povahy prirodzených (majetkových) práv človeka. Tvrdí, že ak Blockovu teóriu dotiahneme do dôsledkov, prídeme k záveru, že naše právo na seba-vlastnenie nie je absolútne, ale kontingentné. Teda, že neexistuje nutne ako právo l'udskej bytosti vyplývajúce z jej prirodzenosti, ale že existuje len náhodne, okrem iného aj ako výsledok vôle rodiča. Evikcionizmus totiž podl’a nej implikuje, že naše práva sú závislé od rozhodnutia matky (mimo tela ktorej, aspoň v určitom štádiu, nedokážeme existovat'). ${ }^{25}$ Ked'že pri samom momente počatia absentuje súhlas matky s našou prítomnost'ou $v$ jej tele (pretože žena nikdy okamžite nevie, že počala), každý z nás podl’a blockovskej logiky vzniká ako „votrelec a kriminálnik“.

Aj toto tvrdenie, ak Baldwinovú správne interpretujem, je však problematické. Block totiž na svoju koncepciu nepotrebuje explicitný súhlas ženy s prítomnost'ou plodu v jej tele. Postačuje mu konkludentný resp. hypotetický súhlas - t. j. kým sa žena nerozhodne plod z tela „vyhostit", nejde o „votrelca“ ani o „kriminálnika“, ale o „vítaného host’a“. ${ }^{26}$ Ak žena nechce byt' tehotná, a, povedzme, že jej zlyhá antikoncepcia, domnievam sa, že v blockovskej logike možno dokonca predpokladat' aj to, že plod je „,votrelcom“ už od momentu počatia. Nejde však o to, že by jeho vznik bol aktom, ktorým plod porušuje

${ }^{21}$ Pričom Baldwinová podotýka, že telo matky sa prirodzene správa tak, aby plod v zásade uvítalo, nie aby ho vypudilo ako, ,votrelca“.

${ }^{22}$ A to aj z radov niektorých súčasných zástancov filozofie Tomáša Akvinského, ktorí odmietajú tvrdenie, že by Tomáš tento argument použil (pozri napríklad: FINNIS, J. M. Prirodzený zákon a prirodzené práva. Bratislava : Kalligram, 2019, s. 97 a 646).

${ }^{23}$ No existujú aj jeho zástancovia (pozri napríklad: FESER, E. In Defense of the Perverted Faculty Argument. In Neo-Scholastic Essays. South Bend : St. Augustine‘s Press, 2015, s. 378 - 415).

${ }^{24}$ ROTHBARD, M. N. Etika Svobody. Praha: Liberální institut, 2009, s. 61 - 63.

${ }^{25} \mathrm{~V}$ prípade umelého oplodnenia by malo v duchu Baldwinovej námietok rovnako platit', že majitel' „skúmavky“ nemá právo z nej zygótu svojvol'ne vyliat’; otázka umelého oplodnenia však teraz nie je podstatná.

${ }^{26}$ C̆o Block napokon v danej diskusii aj výslovne uvádza. 
práva ženy (plod sa predsa sám nestvoril). Povedané právnickým jazykom, ide skôr o protiprávny stav, ${ }^{27}$ ktorý nemá s aktivitou plodu nič spoločné, ale súvisí s jeho holým bytím v tele ženy; ide o mimovôl'ovú skutočnost' spojenú s objektívnou zodpovednost'ou. Z hl'adiska rothbardovského libertarianizmu Baldwinová nemá pravdu ani v tvrdení, že evikcionizmus vedie k záveru o kontingentnej, a nie absolútnej, povahe našich práv. Block predsa zdôrazňuje, že plod má od momentu počatia absolútne negatívne právo nebyt' zabitý (nemá akurát právo byt' tolerovaný „,na cudzom území“, pretože by šlo o pozitívne právo, resp. o právo porušujúce slobodu vlastníctva). Ani Baldwinovej tretí dôvod sa teda nejaví ako presvedčivý.

Zdá sa, že Baldwinovej argumenty nestačia na usvedčenie Blocka z logickej chyby ani z inkoherencie s rothbardovským libertarianizmom. Ba čo viac, Block má priestor kritizovat' Baldwinovú za presadzovanie pozitívneho práva plodu na život, resp. pozitívneho záväzku matky vyživovat' plod vo svojom tele. ${ }^{28}$

Práve v tomto bode však možno, podl'a môjho názoru, uvažovat' o určitom obrate. Ten spočíva v skutočnosti, že Block už dlhodobo tvrdí (a vyslovuje to aj v polemike s Baldwinovou), že žena smie plod z tela ,vyhostit“" len za podmienky, že tento zámer najskôr oznámi svojmu okoliu. Táto „oznamovacia povinnost““ ženy podl’a Blocka nepredstavuje jej pozitívny záväzok (inak by sa Block dostal do rozporu so fundamentálnou libertariánskou ideou uznávania výlučne negatívnych práv a negatívnych záväzkov). Block tvrdí, že treba uplatnit' analógiu s osídl'ovaním územia, ktoré už podl'a Johna Locka nikto nemá právo obsadit' tak, že si vykolíkuje pozemok v tvare koláča s dierou uprostred, pretože vnútorné „územie nikoho“ by ostalo nekolonizovatel’né a druhým l’ud’om by bolo bránené $\mathrm{v}$ ich negatívnom práve na slobodu osídl'ovania (v práve nadobudnút' vlastníctvo prvotnou okupáciou k danému „územiu nikoho“ uprostred). Podl’a Blocka sú rodičovské práva analogické práve k slobode osídl'ovania. Každý rodič, ktorý sa nechce starat' o svoje diet'a, musí umožnit' iným dospelým l’ud'om stat' sa jeho adoptívnymi rodičmi. Obdobné podl'a Blocka platí o „vyhostení“ plodu. Ak sa matka rozhodne napríklad v siedmom mesiaci „vyhostit“ svoj plod a zriect' sa ho, musí ostatným jednotlivcom alebo inštitúciám umožnit', aby sa ho ujali (zaplatili za inkubátor atd’.), ak tak chcú učinit', a musí ich preto najskôr upovedomit' o svojom pláne ,vyhostenia“" plodu. ${ }^{29}$

A tu, domnievam sa, môže Baldwinová zaujímavým spôsobom „vrátit' do hry“ dvomi vzájomne prepojenými argumentmi (ktoré som ju, každopádne, dosial’ nepočul explicitne vyslovit $\left.{ }^{30}\right)$ :

\footnotetext{
${ }^{27}$ FÁBRY, B. - KASINEC, R. - TURČAN, M. Teória práva. Bratislava : Wolters Kluwer, 2019, s. 185.

${ }^{28}$ Pri čom, ako už som uviedol, idea pozitívnych práv a pozitívnych záväzkov je pre libertarianizmus neprijatel'ná. Za zmienku stojí, že Block túto kritiku v polemike s Baldwinovou aj explicitne vyslovuje, pričom Baldwinová sa bráni už spomínaným kontroverzným tvrdením, že záväzok matky starat' sa o plod je prirodzeno-právnym záväzkom a preto nemôže byt' nelegitímny (Reason TV: „What‘s The Correct Libertarian Position on Abortion? A Soho Forum Debate,“ online: https://www.youtube.com/watch?v=OKU_xutF-eQ [07-09-2020]).

${ }^{29}$ Pozri napríklad: BLOCK, W. E. Evictionism is Libertarian; Departurism is Not: Critical Comment on Parr. In Libertarian Papers, 2011 (roč. 3), čl. č. 36, s. 7; BLOCK, W. E. - SMITH, E. - REEL, J. The natural rights of children. In International Journal of Health Policy and Management, 2014 (roč. 2), č. 2, s. 88 - 89.

${ }^{30}$ I ked' niečo čiastočne príbuzné naznačila v rozhovore pre Lions of Liberty, na ktorý som už odkázal v jednej z predchádzajúcich poznámok pod čiarou.
} 
(1) Ak povinnost' ženy upovedomit’ svoje okolie o pláne „vyhostit““ plod z vlastného tela podl'a Blocka v skutočnosti nie je pozitívnou povinnost'ou (zodpovedajúcou pozitívnemu právu okolia dozvediet' sa o možnosti adopcie diet'at'a), ale len negatívnou povinnost'ou (zodpovedajúcou negatívnemu právu okolia nemat' bránené v adopcii diet'at'a), potom ňou nie je ani ženina povinnost' ,nevyhostit“" plod, kým nemá aspoň teoretickú šancu prežit’ mimo jej tela. V čom je aktívne vykonanie úkonu upovedomenia menej ,pozitívne“ než pasívne ponechanie diet'at'a vo svojom tele? V čom je medzi danými záväzkami kvalitatívny rozdiel s ohladom na ich negatívny verzus pozitívny charakter?

(2) Ak sa „negatívna“ povinnost' ženy umožnit' druhým postarat’ sa o jej diet’a týka oznamovacej povinnosti, na základe akého dôvodu ju máme obmedzovat' len na túto povinnost', a nevzt'ahovat' ju aj na povinnost' „nevyhostit““ plod skôr, než má aspoň teoretickú šancu prežit' mimo jej tela? Ak predsa plod po príliš včasnom „vyhostení“ umrie, nebude o koho sa starat' a záujem druhých adoptovat' „vol'né diet’a“ tým bude zmarený (žena im tým vlastne v adopcii zabráni).

Na prvý argument by Block mohol reagovat' tvrdením, že rozdiel medzi notifikačnou povinnost'ou ženy a jej povinnost'ou ,nevyhostit““ plod je v skutočnosti vel'ký, pretože pri tehotenstve nejde len o ,ponechanie plodu v tele“, ale aj o aktívnu starostlivost' tehotnej ženy o svoje telo (a tým aj o plod v ňom). Tým by však nevyriešil otázku kvalitatívneho odlíšenia oboch povinností, čo do ich negatívneho verzus pozitívneho charakteru. Baldwinová by naopak mohla argumentovat', že ak je oznamovacia povinnost' podla Blocka negatívnou povinnostou, a to napriek tomu, že zjavne ide o „pozitívny“ úkon, ktorý musí dotyčná vykonat' (teda, že ide o facere, nie o omittere či pati), ${ }^{31}$ a ak je negatívnou povinnost'ou len z toho dôvodu, že Block uplatňuje analógiu s osídl’ovaním vol'ného územia, potom sa dostávame do situácie, $\mathrm{v}$ ktorej má pojem negatívnej povinnosti relatívne neostré hranice. Prečo túto neostrost' nevztiahnut' aj na povinnost' matky „nevyhostit““ plod zo svojho tela príliš zavčasu? Baldwinová by mohla argumentovat', že v sporných situáciách neistoty o negatívnej verzus pozitívnej povahe určitej povinnosti alebo práva by sme mali zohl'adnit' princíp škody: Plod (ktorý obaja argumentujúci súhlasne pokladajú za l'udskú bytost'), príde stratou života (na základe neistého vyhodnotenia matkinej povinnosti „nevyhostit" "ho ako pozitívnej) o viac, než bude ženu stát' jeho nosenie do dňa, kým plod nenadobudne schopnost' prežit' mimo jej tela. Dôvody uplatnenia tohto princípu by pritom vôbec nemuseli byt' utilitaristické. Mohli by spočívat' v skutočnosti, že strata, ktorú plod utrpí, je ireverzibilná a tým v prípade mylného vyhodnotenia danej povinnosti ako pozitívnej aj nekompenzovatel'ná, zatial' čo stratu ženy možno v prípade uznania omylu pri kvalifikovaní danej povinnosti ako negatívnej (ak sa objaví nejaká preukázatel’ne lepšia teória) neskôr kompenzovat' (a idea kompenzácie škôd je pre libertariánov relevantná).

Vo vzt’ahu k druhému argumentu by zrejme Block odpovedal, že nedostatočná životaschopnost' plodu je prirodzenou skutočnost'ou, za ktorú nikto nemôže (takže záujemcom o jeho adopciu sa v prípade „vyhostenia“ v príliš rannom štádiu, žial', nijakým spôsobom nepodarí zachránit' ho). Baldwinová by však mohla oponovat', že predčasné

\footnotetext{
${ }^{31}$ FÁBRY, B. - KASINEC, R. - TURČAN, M. Teória práva. Bratislava : Wolters Kluwer, 2019, s. 195.
} 
„vyhostenie“ plodu je v prípade analógie s osídl’ovaním územia podobné situácii zničenia časti územia (napríklad odpálenia časti nikomu nepatriaceho útesu, ktorá sa prepadne do mora, čím sa celková osídlitel'ná plocha nad vodou zmenší). Ak majú byt’ kolonizácia územia a adopcia diet'at’a druhým l’ud’om umožnené, potom činy, ktoré majú za svoj nevyhnutný následok ich zánik, musia byt' nelegitímne.

Baldwinová sa okolo dôvodenia tohto druhu čiastočne pohybuje $\mathrm{v}$ jednom $\mathrm{z}$ rozhovorov, ktorý nedávno poskytla, argumentuje tu však trochu inak - evikcionizmus kritizuje za ambivalentnost'. Odkazuje na jeden Blockov článok, v ktorom Block uvádza, že v záujme umožnenia iným postarat' sa o plod, by žena mala pred jeho „vyhostením“ vykonat' všetko, čo je v l'udských silách, aby plod prežil a mohol byt' adoptovaný. Baldwinová podotýka, že je vel'mi nejasné, čo to znamená (a uvádza, že donosenie diet’at’a spadá tiež pod všetko, čo je v l’udských silách). Nie je teda jasné, čo všetko je podl'a Blocka žena povinná pred „,vyhostením“ plodu urobit', takže evickionizmus je ambivalentný. V jej koncepcii to, naopak, jasné je - žena musí plodu poskytnút’ ,jedlo a prístrešie“ (food and shelter) do času životaschopnosti, nič viac. Takže, na rozdiel od evikcionizmu, jej koncepcia ambivalentnost'ou netrpí. ${ }^{32}$

Obe pozície, Baldwinovej i Blocka, majú svoje úskalia. Domnievam sa každopádne, že z hl'adiska rothbardovského libertarianizmu treba dat' za pravdu skôr Blockovi, avšak s tým, že z jeho koncepcie treba vynechat' požiadavku oznamovacej povinnosti ženy, ktorá sa chystá „,vyhostit“" svoj plod (či dokonca tvrdenie, že žena musí urobit' všetko, čo je v jej silách). Zastávam totiž názor, že analógia s osídl'ovaním územia tu zlyháva, respektíve že je neuspokojivá, a že takáto notifikačná povinnost’ ženy by jednoducho predstavovala jej pozitívny záväzok. Ako taká by bola v rozpore s libertariánskou ideou akceptovania výlučne negatívnych práv a povinností (záväzkov). ${ }^{33}$

Ak bude Block na tejto analógii a z nej vyplývajúcich záverov trvat', potom Baldwinovej aj iným libertariánskym zástancom pro-life pozície umožní argumentovat' dvomi už uvedenými spôsobmi a koncepciu evikcionizmu, čo do presvedčivosti, oslabí. V prípade, že sa tejto analógie zriekne, bude mat' z hl'adiska rothbardovského libertarianizmu jednoznačne navrch. ${ }^{34} \mathrm{Ak}$ je však z dôvodu nejakej skrytej nutnosti s ohl'adom na celkovú konzistentnost' evikcionizmu notifikačná povinnost' ženy v skutočnosti neodstránitel'nou súčast’ou tejto teórie, potom má, podl’a môjho názoru, evikcionizmus v konfrontácii s liberatriánskym pro-liferstvom značné problémy. ${ }^{35}$

${ }^{32}$ CLAIR, M. A Paradigm Shift on Abortion? Kerry Baldwin Makes a Libertarian Case for a New Perspective. In Lions of Liberty, online: https://lionsofliberty.com/2020/02/03/26228/?utm_source=rss\&utm_medium $=$ rss\&utm_campaign=26228 [09-09-2020]

${ }^{33}$ Túto analógiu Blockovi dnes niektorí libertariáni explicitne vytýkajú (napríklad Daniel Rothschild) a tvrdia, že pri notifikačnej alebo inej obdobnej povinnosti ženy ide o pozitívny záväzok (pozri napríklad: „Walter Block on Starving Babies“, online: https://www.youtube.com/watch?v=51RgVSuNBEI [09-09-2020]).

${ }^{34}$ Čo, podotýkam, neznamená, že s takto upravenou koncepciou evikcionizmu osobne ideovo súhlasím.

${ }^{35}$ Inou otázkou však je, či samotný rothbardovský libertarianizmus, v ktorého kontexte som v tomto príspevku evikcionizmus i najnovšie námietky proti nemu posudzoval, predstavuje dostatočne rozumnú teóriu, ktorá je hodná nasledovania. K výhradám $\mathrm{k}$ absolutizácii princípu neagresie v libertarianizme pozri napríklad: ZWOLINSKI, M. Six Reasons Libertarians Should Reject the Non-Aggression Principle, online: https://www. libertarianism.org/blog/six-reasons-libertarians-should-reject-non-aggression-principle [10-09-2020]. 


\section{Záver}

V príspevku som sa venoval aktuálnej polemike medzi dvomi libertariánmi (anarcho-kapitalistami), Walterom Blockom a Kerry Baldwinovou, o otázke umelého prerušenia tehotenstva, konkrétne o Blockovej teórii evikcionizmu. Obaja odmietajú súčasné interrupčné praktiky, no líšia sa v otázke možnosti „nechat’ plod zomriet““ mimo matkinho tela. Zatial' čo Baldwinová je v podstate klasická pro-liferka (s určitými libertariánskymi špecifikami spočívajúcimi v uznávaní idey vlastníctva tela), Block, ktorý je síce srdcom tiež pro-lifer, považuje za nutné umožnit' žene ,vyhostit““ plod zo svojho tela, a to bez ohl'adu na jeho životaschopnost'. K tomuto postoju ho vedie dôsledné dot'ahovanie rothbardovských ideí, ktoré Baldwinová čiastočne limituje svojou interpretáciou o prirodzenoprávnej povahe vzt’ahu medzi matkou a plodom.

Predstavil som argumenty oboch strán a podrobil som ich kritike. Ukázal som, že Baldwinovej námietky majú nedostatky a že Blockova koncepcia je z hl'adiska rothbardovského libertarianizmu v zásade presvedčivejšia. Platí to však len za predpokladu, že Block sa vzdá svojho pohl'adu na údajne negatívny charakter záväzku ženy upovedomit' svoje okolie o plánovanom „vyhostení“ plodu a že túto povinnost' nebude postulovat'. V opačnom prípade sa Baldwinovej otvára možnost' argumentovat' legitímnost'ou záväzku matky nosit' plod v svojom tele aspoň do času jeho relatívnej životaschopnosti, čo je, samozrejme, idea, ktorá je s Blockovou originálnou koncepciou evikcionizmu nekompatibilná. Dospel som k záveru, že argumenty, ktoré Baldwinová v polemike s Blockom prezentuje, sa síce z libertariánskeho hl'adiska javia ako nepresvedčivé, avšak z danej perspektívy možno jej pozíciu podporit’ inými argumentmi, ktoré dostávajú priestor práve vd’aka Blockovej téze o notifikačnej povinnosti ženy.

\section{Literatúra}

BERLIN, I. Čtyři eseje o svobodě. Praha : Prostor, 1999, 336 s. ISBN 80-7260-004-4

BLOCK, W, E. Toward a Libertarian Theory of Abortion. In The Libertarian Forum, 1977 (roč. 10), č. 9, s. 290 - 294, online: https://mises.org/library/complete-libertarian-forum-1969-1984 [11-09-2020]

BLOCK, W. E. Toward a Libertarian Theory of Evictionism. In Journal of Family and Economic Issues, 2014 (roč. 35), s. $290-294$

BLOCK, W. E. Response to Wisniewski on Abortion, Round Two. In Libertarian Papers, 2011 (roč. 3), čl. č. 4, s. 1 - 10, online: https://www.researchgate.net/publication/229007250_Response_to_Wisniewski_on_ Abortion Round Two [11-09-2020]

BLOCK, W. E. Response to Wisniewski on Abortion, Round Three. In Libertarian Papers, 2011 (roč. 3), čl. č. 37, s. $1-6$, online: https://www.researchgate.net/publication/339435746_Response_to_Block_on_Abortion_Round_Three [11-09-2020]

BLOCK, W. E. Evictionism is Libertarian; Departurism is Not: Critical Comment on Parr. In Libertarian Papers, 2011 (roč. 3), čl. č. 36., s. 1 - 15, online: https://www.researchgate.net/publication/265103479 EVICTIONISM_IS_LIBERTARIAN_DEPARTURISM_IS_NOT_CRITICAL_COMMENT_ON_PARR [11-09-2020]

BLOCK, W. E., SMITH, E., REEL, J. The natural rights of children. In International Journal of Health Policy and Management, 2014 (roč. 2), č. 2, s. 85 - 89, online: https://www.researchgate.net/publication/260877038 The_Natural_Rights_of_Children [11-09-2020] 
CLAIR, M. A Paradigm Shift on Abortion? Kerry Baldwin Makes a Libertarian Case for a New Perspective. In Lions of Liberty, online: https://lionsofliberty.com/2020/02/03/26228/?utm_source=rss\&utm_medium=rss\&utm_campaign=26228 [09-09-2020]

ČERNÝ, D. Princip dvojího účinku: zabíjení v mezích morálky. Praha : Academia, 2016, 233 s. ISBN 978-80200-2605-7

FÁBRY, B., KASINEC, R., TURČAN, M. Teória práva. Bratislava : Wolters Kluwer, 2019, 321 s. ISBN 97880-571-0127-7

FESER, E. In Defense of the Perverted Faculty Argument. In Neo-Scholastic Essays. South Bend: St. Augustine's Press, 2015, s. 378 - 415. ISBN 978-1-58731-558-9

FINNIS, J. M. Prirodzený zákon a prirodzené práva. Bratislava: Kalligram, 2019, 709 s. ISBN 978-80-8991678-8

GRISILLO, T. Block versus Wiśniewski: Not Over Yet, In Reason Papers, 2015 (roč. 37), č. 2, s. 76 - 78, online: https://reasonpapers.com/wp-content/uploads/2016/02/rp_372_7.pdf [11-09-2020]

LOCKE, J. Two Treatises of Government. Londýn: Thomas Tegg and Co., 1823, online: https://www.yorku.ca/ comninel/courses/3025pdf/Locke.pdf [11-09-2020]

ROTHBARD, M. N. Etika Svobody. Praha : Liberální institut, 2009, 336 s. 978-80-8638-955-4

VALC, J. Má opravdu „každý“ právo na život? In Časopis pro právní vědu a praxi. 2016 (roč. 24), č. 4, s. 597 $-605$

VALC, J. Rekonstrukce práva na život v kontextu vývoje genetických technologií (filozoficko-právní analýza problému). Brno: Právnická fakulta Masarykovy univerzity, 2020, 237 s.

WIŚNIEWSKI, J. B. A Critique of Block on Abortion and Child Abandonment. In Libertarian Papers, 2010 (roč. 2), čl. č. 16, s. 1 - 4, online: https://www.researchgate.net/publication/242578471_A_Critique_of_ Block_on_Abortion_and_Child_Abandonment [11-09-2020]

WIŚNIEWSKI, J. B. Rejoinder to Block's Defense of Evictionism. In Libertarian Papers, 2010 (roč. 2), čl. č. 37, s. 1 - 7, online: https://mises.org/library/rejoinder-block $\%$ E2\%80\%99s-defense-evictionism [11-092020]

WIŚNIEWSKI, J. B. Abortion, Libertarianism, and Evictionism: A Last Word. In Libertarian Papers, 2013 (roč. 5), č. 1, s. 153 - 162, online: https://www.researchgate.net/publication/339435653_Abortion_Libertarianism_and_Evictionism_A_Last_Word [11-09-2020]

ZWOLINSKI, M. Six Reasons Libertarians Should Reject the Non-Aggression Principle, online: https://www. libertarianism.org/blog/six-reasons-libertarians-should-reject-non-aggression-principle [10-09-2020]

Free Man Beyond the Wall Peter R Quinones: „Episode 357: Kerry Baldwin On Her Abortion Debate With Walter Block“, online: https://www.youtube.com/watch?v=NhJ5oDekKsI [09-09-2020]

Libertarian Christian Institute: „Ep 64: The Abortion Debate with Kerry Baldwin“, online: https://www.youtube.com/watch?v=ASvZ21YQ8H4 [11-09-2020]

Patterson in Pursuit: „Ep. 93 - Abortion, Natural Rights, and Evictionism | Dr. Walter Block“, online: https:// www.youtube.com/watch?v=W5ECeLv8BBU [07-09-2020]

Reason TV: „What's The Correct Libertarian Position on Abortion? A Soho Forum Debate,“ online: https:// www.youtube.com/watch?v=OKU_xutF-eQ [07-09-2020]

„Walter Block on Starving Babies“, online: https://www.youtube.com/watch?v=51RgVSuNBEI [09-09-2020] 